\title{
The Experiences of Infection and Prevention Control Nurses (IPCNS) in Cultivating Hand Hygiene
}

\author{
Erna Tsalatsatul Fitriyah¹, Meidiana Dwidiyanti², Luky Dwiantoro ${ }^{3}$
}

${ }^{1}$ Student of Master Program in Nursing, Faculty of Medicine, Diponegoro University Semarang; Lecturer of STIKES Bahrul Ulum, Tambakberas, Jombang, East Java

${ }^{2}$ Division of Mental Health Nursing, Department of Nursing, Faculty of Medicine, Diponegoro University, Semarang

${ }^{3}$ Division of Fundamental of Nursing, Department of Nursing, Faculty of Medicine, Diponegoro University, Semarang

Email: nuranilatifah@gmail.com (correspondence)

\begin{abstract}
Abstrak
HAls merupakan infeksi yang didapatkan pasien selama menjalani prosedur perawatan dan tindakan medis di rumah sakit atau fasilitas kesehatan lainnya setelah $\geq 48$ jam. Memperbaiki praktik hand hygiene dapat menurunkan transmisi pathogen penyebab HAls. IPCN sebagai motor penggerak pencegahan dan pengendalian infeksi seharusnya berperan aktif dalam membudayakan hand hygiene. Namun hingga saat ini IPCN belum optimal dalam menjadikan hand hygiene sebagai budaya di rumah sakit. Untuk mengeksplorasi pengalaman Infection Prevention and Control Nurse (IPCN) dalam membudayakan hand hygiene di Ruang Rawat Inap Rumah Sakit Umum Daerah Semarang. Penelitian kualitatif dengan pendekatan fenomenologi. Sampel diambil dengan cara purposive, meliputi 3 IPCN sebagai partisipan utama, 1 orang IPCO dan 3 orang IPCLN sebagai parisipan triangulasi. Pengumpulan data menggunakan indept interview dengan wawancara semistruktur dan dianalisis menggunakan content analysis. Peneliti mendapatkan 2 tema yaitu (1) ketepatan pelaksanaan edukasi dan pendokumentasiannya penting untuk memberikan pemahaman yang adekuat kepada tenaga medis, non medis, pasien dan keluarga agar mau melaksanakan hand hygiene dengan benar dan (2) Pelaksanaan hand hygiene memerlukan kelengkapan saran prasarana, system monitoring dan evaluasi yang tepat, proses role modeling dan motivasi yang sesuai agar hand hygiene menjadi budaya yang positif. IPCN memiliki pengalaman yang positif dan negatif selama berusaha menjadikan hand hygiene sebagai budaya. IPCN memahami dan sepakat bahwa kemampuannya dalam memilih edukasi yang tepat dan kepekaan terhadap faktor-faktor yang mempengaruhi pelaksanaan hand hygiene dapat memperbaiki pemahaman dan kepatuhan hand hygiene semua pihak. Sehigga pada akhirnya hand hygiene lambat laun namun pasti dapat menjadi salah satu budaya positif di rumah sakit.
\end{abstract}

Kata Kunci : IPCN; Hand Hygiene

\section{Abstract}

Healthcare-Associated Infections (HAIs) are infections that patients get while undergoing treatment and medical procedures in the hospital or other healthcare facilities after more than 48 hours. Improving the quality of hand hygiene practices can reduce pathogen transmission that causes HAls. Infection and Prevention Control Nurses (IPCNs) as the pioneers of infection prevention and control should play an active role in cultivating hand hygiene in the hospital environment. Unfortunately, until the present time, there is evidence that IPCNs have not played their roles optimally in making hand hygiene a culture in the hospital. This study aimed to explore the experiences of IPCNs in cultivating hand hygiene 
at the inpatient wards in a regional hospital in Semarang, Indonesia. This study used a qualitative research design with a phenomenological approach. The samples were recruited using purposive sampling technique, consisting of three IPCNs as the main participants, and one Infection Prevention and Control Officer (IPCO) and three Infection Prevention and Control Link Nurses (IPCLNs) as the triangulation participants. Data were collected using semi-structured in-depth interviews and analyzed using the content analysis. The results revealed two themes. First, the appropriate education implementation and its documentation are important to provide an adequate understanding of medical and non-medical staffs, patients and families so that they are willing to perform hand hygiene properly. Second, the implementation of hand hygiene requires complete infrastructures and facilities, proper monitoring and evaluation system, as well as appropriate role models and motivation so that hand hygiene can become a positive culture. This study concludes that IPCNs have positive and negative experiences while trying to cultivate hand hygiene. IPCNs understand and agree that their ability to provide proper education and sensitivity to the factors affecting the implementation of hand hygiene can improve the people's understanding and compliance with hand hygiene. In the end, hand hygiene will eventually become one of the positive cultures in the hospitals.

Keywords: IPCNs, hand hygiene

Article info:

Article submitted on June 08, 2017

Articles revised on July 19, 2017

Articles received on August 17, 2017

DOI: http://dx.doi.org/10.21927/jnki.2018.6(1).1-15

\section{INTRODUCTION}

The trend of increased prevalence of Healthcare-Associated Infections (HAls), particularly in developing countries such as Indonesia increased by $25 \%$ or more, can prolong the length of stay for patients, increase morbidity and mortality (1), and reduce cost-effectiveness (2). Joint Commission International ( $\mathrm{JCl}$ ) (3), and Hospital Accreditation Commission (HAC) (4) have included infection prevention and control (IPC) in the elements of hospital accreditation assessment. This policy emphasizes that the handling of infection prevention and control by establishing IPC committee has become an obligation for hospitals and other healthcare facilities.

The IPC committee may reduce and prevent HAls if they have a clear program and a quality team. Effective programs of infection prevention and control may reduce the average HAls to $>30 \%$ (5). Standard precaution in the form of hand hygiene is a part of the IPC program. Improving the quality of hand hygiene practices may reduce pathogen transmission in the healthcare services by $25-50 \%$ (6). However, WHO reported that around $61 \%$ of health workers did not comply with the appropriate practice of hand hygiene based on the recommended procedures (5). There are only $20 \%$ to $40 \%$ of health workers in Indonesia who comply with the right practice of hand hygiene (7).

A study by Elies et al in 2014 which involved 58 nurses performing 135 occasions of hand hygiene reported that the nurses' compliance with hand hygiene was $4 \%$ before contacts with patients, $27 \%$ before aseptic/invasive procedures, $67 \%$ after contacts with patients' body fluids, $27 \%$ after contacts with patients, and $59 \%$ after contacts with the environment around the patients (8). The results of hand hygiene audit by IPCNs in a regional hospital in Semarang in 2016 showed the standard's achievement 
of $>80 \%$. The results indicated that $73.06 \%$ of nurses performed hand hygiene before contact with patients, $74.63 \%$ before applying procedures on patients, $100 \%$ after touching the patient's body, $85.50 \%$ after contact with patients, and $73.16 \%$ after touching the surface of the patient's environment. To make hand hygiene a positive culture in the hospitals, cooperation across the health professionals is needed; one of which is the IPCNs.

IPCNs are members of IPC committee who ensure that the infection prevention and control includes all specialists and practitioners in the hospital. IPCNs may act as the coordinator of the IPC team so that the entire team can carry out their duties well (2)(9). Preliminary study results, IPCNs at the research site revealed that the assessment of hand hygiene compliance had not been carried out by the existing regulations. The hospital management's interest related to the necessity of passing an accreditation assessment still became an important consideration in the report of audit results. Furthermore, there was fear that efficiency of procurement of hand hygiene equipment without a comprehensive needs analysis might hinder the achievement of positive cultures of hand hygiene. In order to identify the roots of the problem, this study is necessary to be conducted to know the IPCNs' experiences of cultivating hand hygiene in inpatient wards by exploring the understanding, supporting and inhibiting factors, efforts to minimize obstacles and future expectations related to the implementation of hand hygiene.

\section{MATERIALS AND METHODS}

This study was part of a larger ongoing study employing qualitative research methods with a hermeneutic phenomenological approach. The instruments in this qualitative study were the researchers themselves. The researchers conducted self-validation by participating in the basic Infection Prevention and Control (IPC) training, in which the material on IPCNs was included, on 23-25 February 2017 at RSUD Sidoarjo, East Java. The researchers also developed good relations with experienced training teams and IPCN practitioners to improve the mastery of theory and insights related to IPCN. Furthermore, the researchers also tested the interview guidelines and voice recorders to IPCNs outside the research site to gain more readiness before entering the research field.

This study was carried out at a regional hospital in Semarang, Indonesia from March to May 2017. The population was IPCNs who were involved in the implementation of hand hygiene and infection surveillance programs at the B-type regional hospital in Semarang. B-type hospitals are hospitals that are able to provide extensive specialist medical services and limited subspecialties. This study used purposive sampling to recruit the participants, consisting of three IPCNs as the main participants, and one IPCO and three IPCLNs as the triangulation participants.

Data were collected through in-depth structured interviews for 50-60 minutes for each participant. To collect the data, voice recorders and smartphone recorders were utilized. To ensure the validity of data, the researchers also reviewed relevant documents and observations of the completeness of facilities and infrastructure associated with the implementation of hand hygiene. The collected data were analyzed using inductive content analysis, which included open coding, creating categories and data abstractions (10). The resulted themes and discussions were then confirmed with the main participants.

\section{RESULTS AND DISCUSSION}

In this study, the researchers had identified various keywords, grouped the keywords into certain categories, and developed themes by relating several relevant categories. The following is an overview of the relationship between categories and themes. 


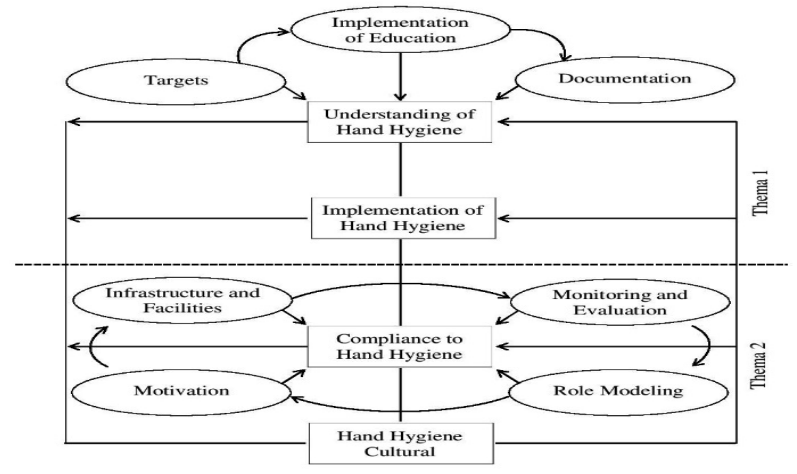

Figure 1. The relationship between categories and themes

As seen in Figure 1, this study revealed two themes. First, the accurate implementation of education and its documentation are important to provide an adequate understanding of medical and non-medical staffs, patients and families, so that they are willing to perform hand hygiene properly. Second, the compliance to hand hygiene implementation requires complete infrastructures and facilities, proper monitoring and evaluation system, and appropriate role models and motivation so that hand hygiene can become a positive culture.

Hand hygiene is part of an easy and the most effective way to reduce infection. However, the consistency to hand hygiene compliance in some health workers is not yet optimal (11). IPCNs need to play their roles and functions to realize the implementation of IPC programs including hand hygiene so that the incidence of HAls can be prevented and controlled (12). IPCNs need to fully understand the factors which can improve understanding of hand hygiene so that all people are committed to perform hygiene correctly and improve their compliance. The following themes illustrate how IPCNs had been involved in the efforts made to cultivate hand hygiene at the research site.
Appropriate implementation of education and documentation is important to provide an adequate understanding of medical, nonmedical, patient and families to perform hand hygiene properly.

IPCNs' views on hand hygiene programs will affect IPCNs in contributing to the program. IPCNs should understand well the meaning of hand hygiene, to whom they should explain about hand hygiene and how to make all people understand and be willing to implement hand hygiene properly.

\section{Meaning of Hand Hygiene}

Results of interviews showed that IPCNs at the research site had understood hand hygiene correctly. Participant (P) 1 stated that "Hand hygiene is important, indeed. Thus, every day we look around to teach hand hygiene to nurses, patients or families ... Hand hygiene has so many benefits ..." (P1)

Participant 2 stated that "... The hand hygiene in this hospital is a program of the infection prevention and control committee. It is also a duty of IPCNs to monitor the implementation of hand hygiene. Hand hygiene has been implemented in all our work areas, which include the inpatient wards, emergency department, surgical wards, and also the offices which do not provide direct services to patients. Hands are a factor which can be a trigger for the chain of transmission ..."

Participant 3 explained that "For the implementation of hand hygiene, what we calculate first is the needs, ... the need for hand hygiene includes the handwash and handrub, ... then we are requested to propose the budget, ... the second is the need to decide the handwash and handrub, ... we also have a germ test, yes, to determine the appropriate products of hand hygiene, ... then the need for hand hygiene is fulfilled after all equipment is installed in the patients' rooms or the hospital 
hallways, .....uncompliance to hand wash can increase the HAls ..."

The depth of IPCNs' understanding may affect the understanding and implementation of hand hygiene in the hospital units. It is because IPCNs are the ones who educate IPCLNs to conduct socialization and monitoring in the units. The results of the content analysis indicated that IPCNs have an adequate understanding of hand hygiene. This can be seen from the statement of triangulation participant 1 which mentioned that "... and hand hygiene implementation is good enough..., The role of IPCN is quite massive ...". Triangulation participant 2 stated, "Hand hygiene has already been implemented in this room, ... it is good for preventing infections ..."

Triangulation participant 3 explained “... what is mostly implemented by nurses is handwash. Even though they have performed handrub in front of the patients, they still do the handwash, ... the nurses' views about hand hygiene here have been positive. ... After a contact with meconium or body fluids, or mothers and babies with hepatitis $B$, they (nurses) will wash their hand and use hand soon with their awareness ..." Triangulation participant 4 also explained "We (nurses) all have done it. Sometimes doctors are not doing that (handwash). It is the nurses who often perform hand hygiene before and after doing interventions for patients ..."

The statements of both main participants and triangulation participants confirmed that adequate understanding of hand hygiene could affect the implementation of hand hygiene. White mentioned that the lack of knowledge and understanding of infection control is an inhibiting factor of good compliance with hand hygiene (13). Compliance with hand hygiene of the health workers in the hospital is very crucial as it will prevent the transfer of microorganisms from nurses to patients, and reduce the incidence of HAls by $25-50 \%$ (6).

\section{Targets of Hand Hygiene}

IPCNs as members of infection prevention and control committee in the hospitals completely realize that it is important to teach hand hygiene to all people in the hospital. Participant 1 stated "...We teach handwash and handrub to nurses, patients, and families..." Participant 2 explained "...We also teach hand hygiene to the third parties, either the parking attendants, canteens and also vendors. What we have done is to monitor the five moments and six steps of hand hygiene. We also teach hand hygiene to those who do not provide direct services, those who are social like visitors, canteens, and also staffs in the office, well ... that's a different moment ..." Participant 3 also mentioned "... handwash and hand rub are taught to the hospital officers, new employees, residents, visitors/companions, and patients..."

Triangulation participant 1 also supported this opinion by stating that "... Hand hygiene has been socialized to doctors, nurses, analysts, structural officers, non-medical staffs, and even to the outsourced cleaning officers..." Furthermore, triangulation participant 2 also stated that "Handwash and hand rubs are socialized to nurses, midwives, doctors, security guards and cleaning officers ..." Triangulation participant 3 argued "... Medical personnel, nurses, midwives, doctors, security guards and cleaning service officers are given training..." Similarly, triangulation participant 4 also stated "...the newly admitted patients are also taught about handrub and handwash...'.

The participants' statements are in line with the fact that hand hygiene is standard practice and one of the most effective strategies for the prevention of infection (14). HAls can affect visitors, family members and health workers (5). Therefore, it is true that teaching adequate hand hygiene to them is important. 


\section{Education Implementation}

The IPCNs are the nurses have got work experience of more than six years, and thus they can understand the characteristics, values, and cultures that exist in their environment. The experiences that they have got so far become one of the considerations to determine how to provide hand hygiene education to those involved in IPC and all people who should receive the education.

This can be seen from the statement of participant 1 , that "...in the past, we gathered IPCLNs and head nurses in a room for socialization. We taught them hand hygiene... We teach hand hygiene to the nurses, patients, and families... For the families and patients, we ask IPCLNs to teach them hand hygiene. When there are new patients, they are also taught about hand hygiene first before they receive an orientation about the room. For example, if the patient is still able to walk, before entering the room, the patient will be given education about hand hygiene, and also the family."

Participant 2 explained "...Yes ... for the first step, ...we taught hand hygiene starting from the socialization. We socialized it to each room, ... yes ... we picked up the ball first. Then, the next step was to organize in-house training. This inhouse training is for all employees. However, the in-house training is not $100 \%$ about PIC, as it is also about hand hygiene. For hand hygiene, in every ceremony occasion, it is continuously socialized..."

Participant 3 explained "...for the leaflet for promotion, yes, thank God we have a third party to help. The leaflet is like that (pointing out a sample in the room). ... Then, there is direct socialization or sometimes through ceremonies. Also, sometimes when we go around, we socialize it (hand hygiene) to the officers, especially the hospital staffs, new employees. There is also socialization for residents, visitors, and patients. We socialize hand hygiene to our visitors although it is not active, in the sense that it is not by our wish for once a month. For patients and visitors, we involve IPCLNs and nurses in the room. In each room, there should be one nurse who trains the patients or the visitors or the companions to perform hand hygiene. We also do the follow-up by asking the patients whether they have been taught hand hygiene or not..."

The statements of these participants were also confirmed by triangulation participant 2 who stated that "... to improve the ability of IPCLNs, the IPCN team has a program like in-house training ... We teach hand hygiene to new patients and families. When I am doing an assessment, I also teach the patient about hand washing. If for example, a patient is coming without the symptom of pain, since this is a delivery room, I still educate the families and companions about hand washing. And for a mother after giving birth, uh... what's the name ... if she wants to hold the baby, she should wash her hands first. In case of a mother with cesarean section, we ask her to wash hand after the postpartum. What matters is that our patients are all healthy. Once the patient arrives, we do anamnesis and teach him/her hand washing. If the patient is in pain, then we will not teach him hand washing first..."

Triangulation participant 3 stated “....Medical teams, nurses, midwives, doctors, security guards and cleaning service officers are given training. ... For the patients and families, we use the education sheets..." Similarly, triangulation participant 4 also explained "...the new patients are taught about handrub and handwash. ...There is an educational sheet. ...IPCLNs should be facilitated for training and seminars related to IPC..."

Valid and research-based information and knowledge of hand hygiene will affect the correct practices of hand hygiene. To successfully improve the compliance to hand hygiene, the programs of education and training which provide accurate and relevant facts are necessary (15). 
The use of personal experience is also a potential means to increase the strength of the existing training methods (16).

\section{Documentation}

Documentation is very important since it serves as the work guideline and evidence of how activities are managed in an organization and provides added values to the organization development. Good documentation also allows for evaluations and new plans for future activities (17). The results of the interviews and document reviews showed that IPCNs had tried to document all their activities even though it was not optimal.

Participant 1 stated that "...the documentation is available (documentation of the implementation of hand hygiene socialization), ... the hand washing audit, ... we report it in three months, ...we often have a discussion almost every month. We discuss with IPCLNs. We meet the Director every three months, ...we have all the reports". Participant 3 said that “...We also ask for a form if there are new patients to whom we introduce hand washing. There is evidence of educating patients ..."

Triangulation participant 2 explained "We keep teaching our new patients and families. We have given the report document to Nurse I. We have given the document..." Triangulation participant 3 informed that "... When we receive the patient, we should give him/her education. Hand washing is listed in the education sheet..." Similarly, triangulation participant 4 also stated, "... so we use the format of educational evaluation."

Results of observation with participant 3 on the completeness of documentation indicated that some activities were not completed with the report documents, such as the activities of simultaneous hand hygiene test and hand hygiene competition. Only the results of the assessment were found for these two activities. The report on hand hygiene socialization to visitors is not yet describing how far the activity has been carried out. Regarding the audit report of hand hygiene compliance of health workers, it was found out that the implementation of hand hygiene (6 steps) was performed monthly. Sometimes, the names and the professions undergoing audit were not written, so that difficulties to present the results of compliance based on the profession, and follow-up to give warning to those people might be encountered. Participant 3 conveyed that such issues would be addressed gradually. For the present time, IPCNs have agreed to focus more on the implementation of IPC programs.

\section{Compliance with hand hygiene requires complete infrastructures and facilities, proper monitoring and evaluation system, and appropriate role models and motivation so that hand hygiene can become a positive culture}

\section{Compliance Level}

Compliance with the implementation of hand hygiene describes the willingness of all elements in the hospital to practice hand hygiene of five moments and six steps correctly. The following statements from participants provide a clear description of the level of compliance with hand hygiene practice at the research site. Participant 1 stated "... Hand hygiene in health sector seems to be neglected, ...thus we provide a form for compliance, ...we calculate the percentage, ...it's rather difficult, this level of compliance, ...it's approximately $70 \%, \ldots$ Compliance is sometimes difficult to achieve,... If we have to leave the form, then it will only be some sorts of formality. As a result, the form may not be appropriately filled out. It is especially related to the prestige of the room. ...Well, if I have to complete 50 forms for my room, I don't think it is good. ...Washing hands after doing interventions are sometimes considered trivial. Some people still perceive hand hygiene negatively, not positively. There 
are people who still feel lazy to do handwashing. It seems that doctors often neglect this hand washing."

Similarly, participant 2 expressed the same opinion. "Yes, ...for the time being, ...yes, ... it is still rather difficult for IPCNs to ensure that all doctors practice hand hygiene exactly in 5 moments or 6 steps. The doctors have practiced the hand wash, but it is not ensured that they are following the six steps. Likewise, colleagues in this room also do the same. Even though they already know the six steps of hand washing, but, in fact, it is not yet reaching $100 \%$... In the past, we used to monitor the problem before we submitted it to IPCLNs, but after we analyzed the results, it was biased. Thus, almost in all rooms, the results were $100 \%$ good (laughs). ... Then we all agreed that IPCNs themselves should fill out the monitoring and audit forms. ... For us, the standard of hand hygiene is $80 \%$. So, the results that we report should be at least $80 \%$. After we do some observations, it turns out that hand hygiene is often missed due to the factors of forgetfulness, being in a rush, busy or workload..."

Triangulation participant 1 also said "At first, before the socialization, we had the five moments of hand hygiene. The lowest score was the moment of contact with patients. Yes, after having contacts with patients, sometimes we forget to wash hands. It happens everywhere. Then, the obstacle is that, hmm, you don't forget, but sometimes because it has become a habit, you don't remember it anymore" Triangulation participant 2 stated "Yes, for our friends, nurses, and midwives, we do hand washing. But for doctors, sometimes they don't do it. Not all doctors perform the hand washing. All nurses do it. We find that some doctors are not doing hand hygiene. That behavior is the obstacle. Yes, sometimes it might be because they forget it. ...Or it could be because they are in a hurry to help patients, so they just wear the hand soon."

The facts mentioned above are in line with the results of a study by Elies et al. which reported that of the five moments, the lowest nurses' compliance to hand hygiene was at the moment of before contacts with patients (8). All participants agreed that this was due to the nurses' behavioral factors. Nurses tend to forget about this because they are in a hurry or feeling lazy.

\section{Infrastructure and Facilities}

The interview results showed that the infrastructure and facilities for hand hygiene are well available. Participant 1 mentioned that "We have been facilitated, both the place, the equipment. ... The procurement of handrub and handwash liquid is already packed. ... I think that is standard, ... the chlorhexidine is $0.5 \%$, and alcohol is $70 \%$. But for hand wash, we usually use $2 \%$ of chlorhexidine except for surgical hand washing; we use $4 \%$. We put the had wash liquid in each bed, and also in the trolley. The SOP is complete."

Participant 2 stated "So, the handscrub is used for hand washing, especially when we are not exposed to the patients' body fluids. We use $0.5 \%$ chlorhexidine of $70 \%$ alcohol-based. We put it in every patient room. Some are mounted on the outside wall. There are also some that are placed on the patient's bed. We also put the handwash liquid in all places that have a sink. We got the products from IPC. The IPC always test the products first when the vendors offer them for use. ... The SPOs are already completed and distributed to all rooms. They are already in the package of IPC SPO.

Participant 3 mentioned "The needs for hand hygiene is fulfilled after they are installed in patient rooms and hospital hallways. It also includes the tissue and so on. But, the use of tissue is limited. If there is accreditation, we provide the tissue. If there isn't, we don't provide it. The problem is that from the data that we 
collect, the tissue is misused. It is not for hand wash but other necessities; it's just like that. In addition, the tissue disposal was also chaotic, at that time. Now, the SOPs already available."

Triangulation participant 1 explained "A few days ago, we conducted an audit for product supply. We have never conducted an audit for handwash liquid so far. We never have a time of running out product supply. Our problem is that we don't have persons who are responsible for checking the liquid, whether it has run out and should be refilled. AT this point, there is not yet control. Sometimes, the tissues in this room are running out. Regarding the SOP, it is already available." Triangulation participant 2 also said "The supporting facilities are already available. They are not running out. It is only about the tissue which is not refilled as its use is limited due to the high cost. Handrub is available in every place and trolley. This room is used for labor. We already have the handrub in every trolley. The hand hygiene SOPs are also available and have been socialized."

Compliance with hand hygiene should have been optimally carried out with the availability of adequate facilities. Damanik et al. stated that the ease in accessing supplies of equipment for carrying out hand hygiene such as hand wash sinks, coir, and alcohol rub is very important to optimize the compliance to hand hygiene implementation (18). Hand hygiene compliance in this hospital is not yet as expected. There are still missed moments and six steps of hand hygiene that have not been properly implemented, although results of observations indicated that the completeness of guidelines and SOPs, as well as the facilities and infrastructure of hand hygiene, had been fulfilled.

\section{Monitoring, Evaluation, and Feedback}

IPCNs have attempted to carry out monitoring and evaluation of the hand hygiene implementation, as well as provide feedback on findings in the hospital units. Participant 1 reported about the hand hygiene assessment: "Usually it is deposited to IPCLNs. It should be filled every day, and we take it, later on, every month for example. We calculate the percentage. We also monitor the implementation every week. We report the results of hand hygiene audit every three months. Regarding the evaluation of five moments, we already have the format and schedule. There is still a need for supervision. We often discuss together almost every month. We discuss with IPCLNs. We meet and give reports to the Director every three months."

Participant 2 explained "We have a responsibility to monitor the hand hygiene implementation. In 2016, we held a test on hand hygiene for almost $90 \%$ of all employees. IPCNs move around the hospital to do their jobs. When it is the schedule for an audit, we bring the checklist. So, watch and observe what is happening and then complete the checklist. The checklist is divided into two; first is for five moments while the other one is for six steps of hand washing. The audit is done five times a month. The results are recapitulated, analyzed and reported."

Triangulation participant 1 stated "We go around doing a hand hygiene audit. IPCNs have been optimal since they travel around every day. So, in addition to supervision and survey, they also see the hand hygiene behaviors of their colleagues. The results of the audit will be informed to all people including doctors, and nurses. They will know the feedback. We also have a regular meeting with IPCLNs. I think the director is quite responsive. For example, if there is a case, she will immediately facilitate it. Triangulation participants 3 stated "We have a solid IPCN team. They are all really solid. The frequently move around the hospital. They are also fast in giving responses. When we report something, they will immediately come."

All programs that have been planned will 
not be optimally implemented if there is no proper monitoring, evaluation and feedback process. Evaluation and feedback should be included in the improvement interventions by monitoring the practice and knowledge among health workers that should be measured (19). An evaluation in the form of audits allows a certain area to identify its need for improvement and inform the needs of continuous improvement in the training documentation (20).

There are two different types of feedback. First is collecting the feedback from the staffs before the audit, education or training interventions to determine the level of self-compliance which can be assessed using a staff perception survey. Second is using audits of direct observations that have been recommended as gold standards to monitor and improve compliance to hand hygiene (21).

The provision of feedback has successfully increased the compliance with hand hygiene six times over the time frames (22). Such techniques as auditing and communication may have different impacts on the compliance culture of hand hygiene. Therefore, ensuring the involvement of staffs and consulting the audit process helps them to remain motivated to increase their involvement (23).

\section{Role Modeling}

Other factors that affect hand hygiene compliance are peer actions and peer pressure (24). For example, hand hygiene compliance among health workers will improve when their senior staffs also comply to hand hygiene ((18), (25)). The role model has been considered as a factor that influences both positive and negative compliance (20). Role models at the research site still need to be established. Until now, the role model of hand hygiene is still referring to IPCNs and IPCLNs in the hospital units. The hospital management personnel and staffs have not been the good role models. The participant statements below illustrate how role modeling is in the research site.

Participant 1 stated "There should be an understanding of what is important. Sometimes, we give examples that the germs are this way and that way. All people in IPC and IPCO care for that. ... We used to have an idea to invite people who have the power. It is just like a role model. But it's just not done yet..."

Participant 2 also mentioned that IPCNs had become the role models in the implementation of hand hygiene programs. "The ceremonial coach.... Usually he/she is the driving representative. $\mathrm{He} /$ she will call some people to come forward, and then we as IPCNs are invited to come forward too. Well, there, we do the hand hygiene together. Each IPCLN has given such directions. IPCLNs socialize that to all their associates in the unit. The associates will socialize hand hygiene with every new patients and companion admitted in the unit. ...We also hoped that the management personnel could be a role model for all health workers. It will help IPCNs to be able to invite all people to comply with hand hygiene." This statement was confirmed by Participant 3 who stated that "The role model has not yet been established. Maybe, in most policies especially in the ones directly associated with the hospital units, there have not been the role models yet."

Triangulation participant 1 said that "The role model still has not been established yet. In our culture, if our friends are, for example, the head nurses, they may not be considered as a role model. So, the issue is how to create a good role model. Sometimes, even though there is someone who is senior and respected in the hospital unit, there is no guarantee that he/she can be a role model." Triangulation participant 4 also said "Yes, we (IPCLNs) also act as a role model too. It happened that the management personnel visited a patient. He did the hand hygiene only after visiting the patient. He did not 
do the hand hygiene before seeing the patient. At this time, IPCNs immediately involved themselves by giving the correct example." (T4)

IPCNs realized that in order all elements of the hospital be willing to carry out hand hygiene appropriately, they require strong role models that would have a positive influence on the compliance to hand hygiene for both new and old staffs. This is in line with a study by Barrett and Rundle which reported that the health workers emphasized the importance of adjusting themselves to the clinical area and the role models of compliance to hand hygiene (26). To be accepted as part of the team, new and inexperienced staffs should adopt the behavior and attitudes of their mentors and other health workers.

\section{Reward and Punishment}

Motivation is a force that encourages individuals to do something to meet the needs at a certain time ((18), (27)). There are several factors that influence the fluctuations of work motivation, consisting of basic factors, i.e., personal motivation and supporting factors in the form of work systems, and driving factors including reward and punishment (28).

Motivation regarding reward and punishment on the implementation of hand hygiene at the research site had not been developed yet. However, IPCNs realize the importance and need for such a system so that the compliance with the implementation of hand hygiene can be increased. Participants 1 and 2 expressed a similar opinion: "We should always remind each other. We have to talk so much about it (hand hygiene).... It is quite difficult to change habits. People need to be forced to do it. We want to have that system (reward and punishment), for example, something should be reduced for those who do not comply with the system. ... Regarding rewards, ... in the past, we proposed that. For example, someone who washed his hands perfectly is given a reward. Even before, there was an idea that the three of us collected something for rewards. Later in every month, if the result of hand hygiene audit is good, we will give the reward. One of the ways to increase motivation is organizing handwashing competitions for hospital units."

Participant 3 explained that the rewardpunishment is not yet officially developed. However, there have been several forms of rewards and punishments that have been carried out. Participant 3 stated "In the past, when the times are approaching the accreditation, during the ceremony, the management personnel invited a few people to come forward individually. They have tested about five moments and six steps of hand hygiene. If the hand hygiene was correct, the five moments were right, six steps were correct, at that moment the person would be given money for IDR 100,000. That's quite much, isn't it? Participating in the competition, attending welcoming sessions of the city mayor or demonstrating hand hygiene, are also some forms of rewards, we think. Regarding the punishment, when it is at the time of the ceremony, and then someone is invited to come forward and perform hand hygiene, but he/she cannot perform it correctly, it is embarrassing for him/her, isn't it? Furthermore, when there is a survey about hand hygiene, the surveyor usually asks for a demonstration. If someone cannot perform the demonstration correctly, and his/ her friends find out this, he/she will, of course, feel ashamed. This is such a social punishment, isn't it?"

Triangulation participant 2 said “... To motivate all people, we have hand hygiene competitions. In the past, the competition was held among the hospital units. That each unit is given a reward from the hospital management, it is not yet implemented. There is no punishment yet for those who violate the hand hygiene compliance. It is different 
from other hospitals. Furthermore, triangulation participant 4 explained "We need to give reminders continuously. Rewards are needed for increasing enthusiasm as well as improving the compliance. Those who are compliant with hand hygiene should be given rewards. There is no punishment yet for those people who were not compliant with hand hygiene."

Employees need rewards or compensation for the work they have done to increase their motivation to achieve the best performance (29). The most important principle is that someone with high achievement should be given appropriate rewards, and someone who does violations of rules in the organization should also be given appropriate and fair punishment. Suryabrata explained that rewards or success would trigger people to continue or repeat the actions that give them rewards or success (30). In contrast, punishment or failure will reduce a tendency to repeat the behavior that brings punishment or failure. Any leaders will not succeed in motivating their employees if they do not appropriately implement a system of reward and punishment. Errors in implementing the reward and punishment system will result in the emergence of demotivation and lack of job satisfaction among the employees (31). If this situation occurs continuously, it can cause low performance of both employees and organizations. Only people with high motivation will be able to improve their performance (32).

\section{Organizational Culture}

Hand hygiene had not become a positive culture in the hospitals where the study was conducted. Performing hand hygiene of five moments and six steps automatically with full awareness has been the hope of many people including the IPCNs. The followings are some statements from the participants related to the hand hygiene that has not been a culture in the hospital.
Participant 1 said "We know that hand washing is a necessity. After touching anything, we should wash our hands. It should be automatically done." Participant 2 explained "Regarding the issue of interpersonal relationships, we still have problems. We still fell reluctant with the doctors when we have to remind them about hand hygiene." Participant 3 said "What we want is that the six steps and five moments of hand hygiene correctly implemented. Anyone should be aware of the importance of hand hygiene and be willing to implement it with good selfawareness." Triangulation participant 3 expected "Hand hygiene should be performed with selfawareness."

Understanding the organizational culture is very important for IPC teams including IPCNs since it is not always formed or formally organized. It is a factor which determines how employees act. An organizational culture that has been deeply entrenched needs harder efforts to change. A large healthcare system tends to implement more formal communication methods, and the decision-making takes a long time. Whereas in the smaller health facilities, the communications are less formal, but the decisions can be taken more quickly. Initiatives and programs may be easier to be implemented in smaller organizations who are not afraid of changes and are interested in new technology. However, the implementation is not the same and so is the ability to support. If the organizational culture supports a program, then the cultural changes may work well. Understanding organizational and working culture is very important for the development, implementation, and ability to support various efforts to prevent infection, including the programs for hand hygiene improvement (14).

Compliance with hand hygiene can be increased and becomes a positive culture if there are specific rules and involvement of the leaders. The compliance may be achieved, for example, by making a policy that it is such a violation when 
someone is not performing hand hygiene, and thus he/she should be given a punishment, just like a violation of patient safety (33).

\section{CONCLUSIONS AND SUGGESTION}

IPCNs had positive and negative experiences while trying to make hand hygiene a culture in the hospital. IPCNs understood and agreed that their ability to choose the appropriate education and sensitivity to the factors affecting the implementation of hand hygiene could improve the understanding and compliance of all people. In the end, hand hygiene will eventually become one of the positive cultures in the hospital.

The role of IPCNs to make hand hygiene a positive culture in the hospital is very important and should be fully supported by the hospital management in the form of policies and infrastructure as well as facilities. Thus, the IPCNs will have the power to carry out their duties. The management should also be committed to receiving the audit results and contribute to improving the compliance to hand hygiene. If the hospital is implementing efficiency, it should be ensured that such policy does not hinder the efforts to realize hand hygiene as a positive culture. Therefore, it is necessary to carry out a needs analysis carefully before the policy is implemented.

This study can be used as the basis for the development of further research, as there might be other problems that are not explored in this study yet. It is also necessary to examine more deeply the causes of the tendency to fulfill the demands to pass accreditation since there is an indication that the hospital used the reports as a formality without considering the reality. Such a situation may have an impact on patient safety and the overall quality of hospital services. Furthermore, it is also necessary to conduct a comprehensive study related to the factors affecting the implementation of efficiency so that it will not hinder the established compliance with the hand hygiene implementation.

\section{REFERENCES}

1. Bearman et al. A Guide to Infection Control in The Hospital. Fifth Edition. International Society for Infectious Diseases. Boston. MA USA. 2014.

2. Departemen Kesehatan Republik Indonesia. Pedoman Managerial Pencegahan dan Pengendalian Infeksi di Rumah Sakit dan Fasilitas Pelayanan Kesehatan Lainnya. Jakarta. 2008

3. Joint Commission International. Accreditation Standards For Hospitals. $5^{\text {th }}$ Edition. 1 April 2014

4. Kerjasama Direktorat Jenderal Bina Upaya Kesehatan Kementerian Kesehatan Republik Indonesia dengan Komisi Akreditasi Rumah Sakit (KARS). Standar Akreditasi Rumah Sakit. 2012

5. WHO. Health Care Without Avoidable Invection. The Critical Role of Infection Prevention and Control. 2016.

6. Quality Medical Care Section. Medical Development Division. Policies and Procedures on Infection Control. Ministry of Health Malaysia. $2^{\text {nd }}$ Edition. 2010.

7. Akmal Taher. Kebersihan Tangan Mempengaruhi Keselamatan Pasien. Pusat Komunikasi Publik, Sekretariat Jenderal Departemen Kesehatan. Nopemper 2009. Info@puskom.depkes.go.id.

8. Elies. Asih \& Sastra 2014. Penerapan Hand Hygiene Perawat di Ruang Rawat Inap Rumah Sakit. Jurnal Kedokteran Brawijaya. Vol. 28, Suplemen No.1.

9. International Federation of Infection Control. IFIC Basic Concept of Infection Control. Previously Published as Infection Contro: Basic Concepts and Training. $2^{\text {nd }}$ Edition. Revised 2011. 
10. Elo S. \& Kyngas H. The Qualitative Content Analysis Process. Journal of Advanced Nursing 62 (1), 107-115. Doi:1111/j.13652648.2007.04569.x. 2008.

11. Janet E Squires, Kathryn N Suh, Stefanie Linklater, Natalie Bruce, Kathleen Gartke, Ian D Graham, Alan Karovitch et. al. Improving Physician Hand Hygiene Compliance Using Behavioural Theories: A Study Protocol. Squires et al. Implementation Science 2013, http://www.implementationscience.com/ content/8/1/16

12. Costy Pandjaitan. Peran dan Fungsi IPCN. Disampaikan pada acara Pelatihan Pencegahan dan Pengendalian Infeksi Dasar. Perdalin \& HIPPII Semarang. 22-24 Januari 2015

13. Katherine $M$ White, Nerina $L$ Jimmieson, Patricia L Obst, Nicholas Graves, Adrian Barnett, Wendell Cockshaw, Philip Gee et al. Using The Theory o Planned Behaviour Framework to Explore Hand Hygiene Beliefs at ' 5 Critical Moments' Among Australian Hospital-based Nurses. White et al. BMC Health Services Reseach 2015. DOI 10.1186/ s12913-015-0718-2

14. Association for Professional in Infection Control and Epidemiology. APIC Implementation Guide. Guide to Hand Hygiene Programs for Infection Prevention. Washington. 2015.

15. Eveillard, M., Raymond, F., Guilloteau, V., Pradelle, M.T., Kempf, M., Zilli-Dewaele, M., Joly-Guillou, M.L. and Brunel, P. Impacts Of A Multifaceted Training Intervention On The Improvement Of Hand Hygiene And Gloving Practices In Four Healthcare Settings Including Nursing Homes, Acute-Care Geriatric Wards And Physical Rehabilitation Units. Journal of Clinical Nursing, 20, pp. 2744-2751. 2011.

16. Nicol, P. W., Watkins, R. E., Donavan, R. J., Wyanaden, D. and Cadwallader, $\mathrm{H}$. The
Power Of Vivid Experience In Hand Hygiene Compliance. Journal of Hospital Infection, 72, pp. 36-42. 2009.

17. Dokumentasi Sistem Manajemen Mutu ISO 9001: 2008. http://checklist-magazine.com/ dokumentasi-iso-900122008.

18. Monica P Waney, Grace D Kandou, Jimmy Panelewen. Faktor-Faktor Yang berhubungan Dengan Penerapan Hand Hygiene di Instalasi Rawat Inap Rumah Sakit Tingkat III R. W. Monginsidi Manado. 2016

19. Aziz, A.M. Hand Hygiene Compliance For Patient Safety. British Journal of Healthcare Management, 20(9), pp. 428-434. 2014.

20. Wyeth J. Hand Hygiene and The Use of Personal Protective Equipment. British Journal of Nursing. 22 (16), 920-925. 2013.

21. World Health Organization (WHO). A Guide to The Implementation Of The WHO Multimodal Hand Hygiene Improvement Strategy. WHO. Geneva. 2009.

22. Creedon, S.A. Hand Hygiene Compliance: Exploring Variations In Practice Between Hospitals. Nursing Times, 104(49), pp. 3235. 2008.

23. Aziz, A.M. How Better Availability Of Materials Improved Hand-Hygiene Compliance. British Journal of Nursing, 22(8), pp. 458-463. 2013.

24. Sax, H., Allegranzi, B., Ucjay, I., Larson, E., Boyce, J. and Pittet, D. My Five Moments For Hand Hygiene: A User-Centred Design Approach To Understand, Train, Monitor And Report Hand Hygiene. Journal of Hospital Infection, 67, pp. 9-21. 2007.

25. Noreen Hynes. A Hand Hygiene Education and Training Improvement Strategy in an Acute Hospital Setting. Royal College of Surgeons in Ireland. E-publications@RCSI. Theses. 1-1-2015

26. Barrett, R. and Randle, J. (2008) Hand Hygiene Practices: Nursing Students' 
Perceptions. Journal of Clinical Nursing, 17, pp. 1851-1857. 2008.

27. Henki Idris Issakh \& Zahrida Wiryawan. Pengantar Manajemen. Edisi 2. In Media. Jakarta. 2015.

28. Ernie Tisnawati Sule \& Kurniawan Saefullah. Pengantar Manajemen. Edisi Pertama. Penerbit Prenamedia Group. Jakarta. 2015.

29. Wibowo. Manajemen Kinerja Divisi Buku Perguruan Tinggi. PT Raja Grafindo Persada. Jakarta. 2007.

30. Suryabrata, Sumadi. Psikologi Pendidikan. Edisi 5. Rajawali Pres. Jakarta. 2010.

31. Suharli, Michell J J. Habbit: Delapan Kebiasaan Yang Mengubah Nasib Anda. Gramedia Pustaka Utama. Jakarta. 2009.

32. Pangisti Dwi Ananingsih, Elsye Maria Rosa. Kepatuhan 5 Momen Hand Hygiene
Pada Petugasi di Laboratorium Klinik Cito Yogyakarta. Jurnal Medicoeticolegal dan Manajemen Rumah Sakit, 5 (1): 16-24, Januari 2016. DOI: 10.18196/jmmr.5102

33. Elizabeth Mclnnes, Rosemary Phillips, Sandy Middleton, and Dinah Gould. A Qualitative Study of Senior Hospital Managers Views on Current and Innovative Strategies to Improve Hand Hygiene. Mclnnes et al. BMC Infectious Diseases 2014. http://www.biomedcentral. com/1471-2334/14/611

34. Setiawati. Analisis Faktor-Faktor Yang Mempengaruhi Ketaatan Petugas Kesehatan Melakukan Hand Hygiene Dalam Mencegah Infeksi Nosokomial di Ruang Perinatologi RSUPN Dr. Cipto Mangunkusumo Jakarta. FIK UI. Tesis. 2009 